\title{
Infiltration of Wayang to the Literary order in the Javanese Bridal Ceremony
}

\author{
Suwarna $^{1}$, Erna Istikomah ${ }^{2}$, Sri Hertanti Wulan ${ }^{3}$, Nurhidayati $^{4}$ \\ \{1'suwarna@uny.ac.id, ${ }^{2}$ erna.istikomah@uny.a.id, ${ }^{3}$ hertanti_wulan@uny.ac.id, ${ }^{4}$ nurhidayati@uny.ac.id\} \\ 1,2,3,4 Department of Javanese Language Education Faculty of Language and Art Yogyakarta State \\ University
}

\begin{abstract}
This study aims to explore and elaborate the infiltration of various wayang performances on literary order in Javanese bridal ceremonies. The subjects of the study were Javanese bridal ceremonies, Javanese bride ceremony documents (references, photos, videos, audio) and speakers (pranatacara and dalang). Research instruments using observation sheets, questionnaires, interview guides, potography, and videography. Ratification of data by means of intrarater, interrater, check and richek, peer discussion, with verification to pranatacara and dalang. The results of the study were analyzed qualitatively with the steps of identification, inventory, codification, comparison (wayang performances and wedding ceremony performances), description, explanation and elaboration, and inference. The results showed that wayang was infiltrated into the Javanese bridal ceremony for the first time when Sri Susuhunan Paku Buwana IV in Surakarta Hadiningrat's palace married his daughter with the act of Parta Krama. As the story progresses, the other stories also include: Permadi Jinambang and Bima-Arimbi (Lampahan Babat Alas Mrentani), Arjuna Sasrabahu, Gatotkaca Pergiwa, Alap-alapan Sukesi, Gandamana, PermadiSembrada (Lampahan Kangsa Adu Jago), Dewa Ruci, Lampahan PergiwaPergiwati, Lampahan Abimanyu Krama, Murwakala, and Pista Andrawina. These various stories infiltrate literary order in Javanese bridal ceremonies in terms of: 1) Language style, 2) Taxation/ Purwakanthi 3) Paribasan, 4) Bebasan, 5) Saloka, 6) Parikan/pantun, 7) Panyandra, 8) Wangsalan, 9) Sasmita gending, 10) Sabdatama and 11) Jokes.
\end{abstract}

Keywords: wayang, infiltration, literary order, Javanese bridal ceremony

\section{Introduction}

This research is very important because it can be a supporter of the main competencies for prospective teacher students and as an entrepreneurial capital become a professional host. The main competence refers to that students of the Java Language Study Program are prospective Javanese language teachers. Pranatacara (a host) is a professional skill as a profession in cultural practice that can contribute to cultural preservation and the development of cultural entrepreneurship[1] [11] [16]. 


\section{Research Method}

This study applies a qualitative research with a naturalistic qualitative design [2] [3]. Subjects of the research are Javanese bridal ceremonies, Javanese bride ceremony documents (references, photos, videos, audio), and resource persons (pranatacara and dalang). Research instruments using observation sheets, questionnaires, interview guides, potography, and videography. Ratification of data by means of intrarater, interrater, check and richek, peer discussion, with verification to professional pranatacara and dalang. The results of the study were analyzed qualitatively with the steps of identification, inventory, codification, comparison (puppet shows and wedding ceremony performances), description, explanation, elaboration, and inference.

\section{Results And Discussion}

The historical background of the infiltration of wayang performances in the bridal ceremony was when Sri Susuhunan Paku Buwana IV in Surakarta Hadiningrat's married his daughter. The attendant who delivered the event was a puppeteer. The wedding ceremony was completed by holding a shadow wayang's show with Parta Krama's act. This research encompasses data through observations of bridal ceremonies, and interviews with professional pranatacara who are also dalang (the masterminds), namely: Dr. Wigung Wratsangka, Faizal Noor Singgih, and Jack Haryanto. What is meant by literary order is the use of beautiful language in a bridal ceremony [7] [8]. It can be observed in the following table [7] [9] [10].

Table 1: Infiltration of Wayang to the Literary order in the Javanese Bridal Ceremony

\begin{tabular}{lll}
\hline No. & Literary Order & Detail \\
\hline 1. & Language style & $\begin{array}{l}\text { 1. Hyperbole } \\
\text { 2. Metaphor }\end{array}$ \\
& & $\begin{array}{l}\text { 3. Simile } \\
\text { 2. }\end{array}$ \\
& Taxation/ Purwakanthi & 1. Guru swara \\
& 2. Guru sastra \\
3. & Paribasan & not connotation, standard variety, no subject matter \\
4. & Bebasan & connotation, standard variety, has no subject \\
5. & Saloka & connotation, standard variety, subject \\
6. & Parikan/Pantun & attachments and contents \\
7. & Panyandra & literature for people, goods and atmosphere \\
8. & Wangsalan & attachments and answers \\
9. & Sasmita gending & code name gending in utterance \\
10. & Sabdatama & beautiful advice \\
11. & Jokes & make people smile or laugh \\
\hline
\end{tabular}

a. Language style

1) Hyperbole

The style of hyperbole is exaggerating from the real situation. Exaggerating in hyperbole to warm. Exaggerating this is not a common thing in the speech of the host, thanking the stakeholders, making literary language (beautiful). Research data appear in bold. Example: Sang pamengku karsa dahat amara suka rumaos bombong berawaning manah kadya kebanan 
seganten madu, kajugrugan ing wukir sari 'the stakeholders are very happy, like being flooded with honey, the collapse of the developing mountains'.

2) Metaphor

Metaphor is comparing something with others but not using words that mean something like. Words that contain implicit comparisons. Example:Barisane para kenya srikandhi ning praja Nuswantara 'Rows of girls like the Srikandi Nuswantara'

3) Simile

Simile language styles also make comparisons like metaphors, but in simile the speaker uses words like, like, or lir, kadya, pendah, yayah 'like'. These comparisons words are written. Simile in Javanese literature is called pepindhan (Padmosoekotjo, 1968) [4]. Simile or pepindhan is very productive in the speech of the host, especially in panyandra. Panyandra is describing people, things, or situations in beautiful language. In general, panyandra uses comparisons. That is why simile or pepindhan is very productive in panyandra because panyandra makes comparisons. Example: Risang pengantin putri miyos saking panti busana kadya puspawarane 'The bride comes out of the dressing room like a beautiful flower'.

b. Taxation/ Purwakanthi

Taxation in the study of Javanese literature is called purwakanthi [12]. There are three Purwakanthi, namely purwakanthi guru swara, guru sastra and guru basallumakasita. Purwakanthi swara teacher is a vocal repetition at the end of a word in a speech that gives rise to beauty. Example: Apa kang sinedya dadya, kang kaesthi bakal dumadi 'What is aspired to be achieved'. Purwakanthi guru sastra is a consonant repetition in a number of speeches from a host. The consonant position is at the beginning, middle, or end of words. Example: Jumbuh gambuh kang samya ginayuh, kadya kekudanganira para pinisepuh 'What was reported was achieved as parents' expectations'. Purwakanthi guru basa or lumaksita is a repetition of words in a speech of pranatacara. Example: Carang wreksa, wreksa wilis tanpa patra, ora gampang mangun brayan kulawarga "Green tree branches without leaves (leaf branches are called pang), it is not easy (easy) to build a family life.'

c. Paribasan

Paribasan is a variety of standard idioms, consistent in the use of speech, generally does not use conotation and has no subject. Brings are used for flapping. As a frozen variety idiom, its use should not be fruited (for example, it is made into krama language - it should not be) because the idiom would be strange in the ears of Javanese culture and not beautiful. If there are changes, it is very limited. Example: Bokbilih anggen kula ngaturaken pambagya harja kaduk wani kurang deduga, kula nyuwun agunging pangaksama 'If my speech feels too presumptuous, please forgive me'.

\section{d. Bebasan}

Unlike paribasan, bebasan uses the conotation words. Limitation also includes idioms, standard variations, and consistent use. A burden also has no subject, but it uses words. Example:Risang penganten putra dadya wanodya kang gemi nastiti lan ngati-ati, nora hanggenthong umos 'The bride becomes a woman who really appreciates fortune and not wasteful'.

\section{e. Saloka}

The main characteristic of Saloka is having a subject. Saloka is also a frozen variety of ideas, consistent in usage, and using fancy words. Example: Risang panganten, keplok lair batine, salokane curiga manjing waranga, warangka manjing curiga 'The bride is very harmonious, like a keris coming into a frame, a frame for a dagger'. 


\section{f. Parikan}

In Indonesian literature, parikan is called pantun [7] [12]. Parikan consists of sampiran utterances at the beginning and answers or contents in the second part. The most widely used is parikan 2 and 4 lines. If the parikan consists of 2 lines, line 1 contains sampiran and line 2 contains answers/contents. If the parikan contains 4 lines, lines 1-2 contain sampiran and lines 3-4 contain answers/contents. Between sampiran and answer has poetry or equality (purwakanthi). Example: Bapak Ibu kersaa nyebar godhong kara, sabar sawerata, adicara siraman tumuli badhe kawiwitan 'Ladies and gentlemen, please be patient, the siraman ceremony will start'.

g. Panyandra

Panyandra is describing people, goods, and situations using beautiful language (Padmosoekotjo, 1968) [4]. Besides panyandra there is what is called janturan. The following table is a comparison (Suwarna, 1998, 2017) [5] [6] [15].

Table 2: Comparison between panyandra and janturan

\begin{tabular}{|c|c|c|}
\hline No. & Panyandra & Janturan \\
\hline 1 & Describe in beautiful language & Describe in beautiful language \\
\hline 2 & $\begin{array}{l}\text { What is described: people, goods, and } \\
\text { situations }\end{array}$ & What is described: people, goods, and situations \\
\hline 3 & $\begin{array}{l}\text { Melodic speech with beautiful tempo and } \\
\text { dynamics }\end{array}$ & $\begin{array}{l}\text { Melodic speech with beautiful tempo and } \\
\text { dynamics }\end{array}$ \\
\hline 4 & $\begin{array}{l}\text { Speech is accompanied by gending ketawang } \\
\text { or ladrang }\end{array}$ & $\begin{array}{l}\text { Speech is accompanied by gending ketawang or } \\
\text { ladrang }\end{array}$ \\
\hline 5 & $\begin{array}{l}\text { Spoken at times that are not necessarily } \\
\text { understood by guests listeners. But listeners } \\
\text { can appreciate the beauty of the speeches. }\end{array}$ & $\begin{array}{l}\text { Spoken at times that are not necessarily } \\
\text { understood by guests/listeners. But listeners can } \\
\text { appreciate the beauty of the speeches. }\end{array}$ \\
\hline 6 & What is described is concrete (observable) & What is described: abstract (unobservable) \\
\hline
\end{tabular}

What distinguishes between panyandraan and janturan is concrete and abstract. If panyandra to describe people, goods, or concrete situations, while janturan to describe people, goods, or situations that are abstract. Example:

(1) Panyandra: Sri hatmaja pengantin hangagem busana Paes Ageng Kanigaran Kasulatanan Nyayogyakarta Hadiningrat. Kuluk makutho kanigara warni langking pinalipit prada kemasan, kinarya pralambang jejerning nata berbudi bawa leksana. Cundhuk mentul setunggal pethat mungkur mapane pralampita muhung hangesti panguwasaning Gusti Kang Mahaesa. 'The bride is wearing the Paes Ageng Kanigaran Ngayogyakarta Hadiningrat Sultanate clothing. Kuluk makutho kanigara's is black, squeezed by golden prada, symbolizes a wise king. Cundhuk mentul one facing behind the symbol that the king always devoted to God Almighty. '

(2) Janturan: Ngaturaken pambagya kawilujengan sinuba sinukarta kaiiring jatining pakurmatan dhumateng para rawuh. Hawit doa pangestu Jawa panjenengan, sri penganten sageda manggih kamulyan, karaharja, miwah katentreman. 'Make a welcome to guests. May the prayers of the guests deliver the bride to a noble, happy and peaceful life.

\section{h. Wangsalan}

Wangsalan is a narrative that has sampiran and content or answers as in the pantun. Attachments to the ward provide clue answers. Content is the answer from sampiran. Sampiran generally refers to an item and refers to one or more syllables. Example: Sowan kula 
menika kajibah ndhodhog lawan korine, nginang jambe suruhe, awit anak kula ngebun-ebun enjang anjejawah sonten. 'I came to propose, because my son asked to be married'. Ebun enjang is suwun, jawah sonten is nyuwun rabi.

i. $\quad$ Sasmita gending

Sasmita gendhing is a host code delivered by gamelan musicians or operators [9] [14]. The technique to make sasmita gendhing is to combine the events that will occur, the desired gending name, and the surrounding situation [17]. Sasmita gendhing is one indicator of the intelligence of the host. In sasmita gendhing, the host must consider the event to be held, the name of the gending, and the situation. This means that if the host wants a particular genre, consider the event and the situation. In making sasmita gending, the pranatacara (host) will consider the event, the name of the gending, and the situation. The event attendant must find a match between the name of the event and the name of the gending and consider the situation. How to convey sasmita gendhing (1) in narrative speech and (2) open-mouthing. Narrative utterances are descriptive ceremonial utterances. Unpainted begins the gending. Open hugged delivered with songs.

(1) Narrative sasmita gendhing

Pinaringan puji pandonga, sri pengantin mugi hamanggih rahayu. 'Given the blessing, the bride may meet salvation'.

Sasmita gendhing is to ask for the name of Ladrang Mugi Rahayu to the gamelan player (pangrawit) and or waranggana. The words mugi and rahayu are mentioned in sasmita gendhing to give code to pangrawit and waranggana that they are asked to present the Ladrang Mugi Rahayu Slendro Pathet 9 gending.

(2) Buka celuk sasmita gendhing

Sri pengantin arsa tedhak aneng dhampar denta adi... 'The bride will sit on the throne'.

Sri pengantin arsa tedhak aneng dhampar denta adi....sung in the form of song. Open the tap to begin the gending Ketawang Padhang Bulan Slendro Manyura. Gending Padhang Bulan (as the name implies) is actually more appropriate to accompany the bride at the bridal reception at night. This tap open can be applied at night and daytime. The first line of gending Padhang Bulan is Padhang bulan gegencaran, nedhenge purnomo sidhi... replaced Sri pengantin arsa tedhak aneng dhampar denta adi....

Buka celuk Padhang bulan gegencaran, nedhenge purnomo sidhi....only right at night. Therefore, if the gending will be echoed during the day, the first line is replaced by using buka celuk Sri pengantin arsa tedhak aneng dhampar denta adi....

j. Sabdatama

Sabdatama is the main or beautiful advice [13] [18]. Beautiful advice can be delivered by the elders at the time of giving a speech or a ceremony at speech spell. Sabdatama is found in wayang and wedding ceremonies. Wayang also provides guidance (besides spectacle). Likewise at a bridal ceremony. The bridal ceremony also provides sabdatama. Example:

Panca Utamaning Gesang Balewisma

Kabrayan : have children

Kahartan : cheap sustenance

Kawiryan : have a position/honor

Kayuswan : a useful longevity

Kawibawan : authoritative because of nobility (Panuntun, 1994) [13 ].

k. Jokes

Both in wayang and bridal ceremonies there are jokes. Jokes are needed for the bridal ceremony situation to be fluid and pleasant [19]. 


\section{Conclusion}

The results showed that wayang was infiltrated into the Javanese bridal ceremony for the first time when Sri Susuhunan Paku Buwana IV in Surakarta Hadiningrat's palace married his daughter with the act of Parta Krama. As the story progresses, the other stories also include: Permadi Jinambang and Bima-Arimbi (Lampahan Babat Alas Mrentani), Arjuna Sasrabahu, Gatotkaca Pergiwa, Alap-alapan Sukesi, Gandamana, Permadi-Sembrada (Lampahan Kangsa Adu Jago), Dewa Ruci, Lampahan Pergiwa-Pergiwati, Lampahan Abimanyu Krama, Murwakala, and Pista Andrawina. These various stories infiltrate literary order in Javanese bridal ceremonies in terms of: 1) Language style, 2) Taxation/ Purwakanthi 3) Paribasan, 4) Bebasan, 5) Saloka, 6) Parikan/pantun, 7) Panyandra, 8) Wangsalan, 9) Sasmita gending, 10) Sabdatama and 11) Jokes.

\section{References}

[1] Suwarna Dwijanagoro, Pengembangan Bahan Ajar Olah Suara dalam Perkuliahan Pranatacara. Yogyakarta: FBS UNY, 2017.

[2] H.B. Sutopo, Metode Penelitian Kualitatif: Dasar Teori dan Terapannya dalam Penelitian. Surakarta: UNS Press, 2002.

[3] J. W. Creswell, Research Design: Qualitative, Quantitative, and Mixed Methods Approaches. Fourth Edition, Fourth. SAGE Publication, Inc., 2014.

[4] Soepomo Poedjosoedarmo, dkk, Ragam Panggung dalam Bahasa Jawa. Jakarta: Pusat Pembinaan dan Pengembangan Bahasa, 1986.

[5] Suwarna Pringgawidagda, Gita Wicara Jawi. Yogyakarta: Kanisius, 1998.

[6] Suwarna Dwijonagoro, dkk; Character Education in Banjaran Bima Play and Its Implication in Javanese Language Learning. Yogyakarta State University: Faculty of Language and Art, 2017.

[7] Gorys Keraf, Diksi dan Gaya Bahasa. Jakarta: Nusa Indah, 1981.

[8] Suwarna Pringgawidagda, Tata Upacara dan Wicara. Yogyakarta: Kanisius, 2006.

[9] Suwarna Pringgawidagda, Gita Wicara Jawi. Yogyakarta: Kanisius, 1998.

[10] Suwarna Pringgawidagda, Bahasa Pewara. Yogyakarta: Pustaka Pelajar, 2009.

[11] Kuswa Endah, Pranata Sosial dalam Masyarakat Jawa. Yogyakarta: Grafika Indah, 2009.

[12] R.NG Poerbatjaraka, Kapoestakan Djawi. Djakarta: Djambatan, 1953.

[13] S Rekso Panuntun, Sekar Sumawur Ngrewat Tuladha Pidhato Basa Jawi. Sukoharjo, Surakata: C.V. Cendrawasih, 1994.

[14] Budiono Herusatoto, Simbolisme dalam Budaya Jawa. Yogyakarta: PT Hanindita, 1987.

[15] Soepomo Poedjosoedarmo, dkk, Ragam Panggung dalam Bahasa Jawa. Jakarta: Pusat Pembinaan dan Pengembangan Bahasa, 1986.

[16] Kuswa Endah, Pranata Sosial dalam Masyarakat Jawa. Yogyakarta: Grafika Indah, 2009.

[17] Suwaji Bastomi, Seni dan Budaya Jawa. Semarang: IKIP Semarang Press, 1992.

[18] Thomas Bratawijaya, Mengungkap dan Mengenal Budaya Jawa. Jakarta: Pradnya Paramita, 1997.

[19] K. Saddhono, "Integrating culture in Indonesian language learning for foreign speakers at Indonesian universities,” J. Lang. Lit., vol. 6, no. 2, 2015. 